\title{
ISOLASI BAKTERI PENGHASIL SELULOSA DARI BUAH-BUAHAN DIPASAR TRADISIONAL MAKASSAR
}

\author{
Herwin, Fitriana, Ayyub Harly Nurung \\ Fakultas Farmasi, Universitas Muslim Indonesia, Makassar \\ Email: herwin@umi.ac.id
}

\begin{abstract}
Isolation of bacterial cellulose from fruits in traditional market of Makassar have been done. The objective of this research is to adding diversity of microorganism that can producing cellulose and observe it's both optimum temperature and $\mathrm{pH}$. First step is isolation of bacteria from Watermelon, Papaya, Cantaloupe, Mango, Dragon fruit, and Banana that found in traditional market in Makassar using Hestrin-Schramm (HS) agar. Each colony bacteria have been separated to making pure culture using HS agar then the colony was screening in HS broth to obtain colony bacteria that producing cellulose. Screening test found that 10 isolate that can produce cellulose which is MB-B02, MS-B01, MS-B03, NB-B03, PB-B01, PB-B02, PB-B03, PB-B04, PS-B01, and PS-B03. Then the colony that producing cellulose was optimize its temperature and $\mathrm{pH}$. Cellulose obtained from optimization was measure it's weight to determine optimum temperature and $\mathrm{pH}$. Based from optimization found that $25^{\circ} \mathrm{C}$ was optimum temperature for MS-B01, MS-B03, NB-B03, dan PB-B04, and $37^{\circ}$ was optimum temperature for MB-B02, PB-B01, PB-B03, PS-B01, dan PS-B03, meanwhile for isolate PB-B02 optimum both in $25^{\circ} \mathrm{C}$ dan $37^{\circ} \mathrm{C}$ dan $\mathrm{pH}$ optimum for all isolate is $\mathrm{pH} 6$.
\end{abstract}

Key word: Bacterial cellulose, fruits from traditional market, Makassar, Optimizing temperature, optimizing $\mathrm{pH}$.

\section{PENDAHULUAN}

Selulosa merupakan biopolimer utama di Bumi dan memiliki nilai ekonomi yang besar secara global. Selulosa yang disintesis dari tanaman diperkiran berjumlah 1012 ton. Tanaman memiliki sekitar $33 \%$ selulosa, pohonan mengandung $50 \%$ selulosa, sedangkan kapas memiliki $90 \%$ selulosa. Selulosa yang berasal dari tanaman, pohon dan kapas diperoleh dari penumpukan glukosa yang diproduksi oleh sel tanaman melalui proses fotosintesis. ${ }^{1}$

Dalam bidang kefarmasian selulosa dan turunannya merupakan salah satu bahan tambahan yang sering digunakan dalam bahan dan produk farmasi dengan berbagai macam tujuan atau fungsi. Dari beberapa kegunaannya, selulosa paling sering digunakan sebagai bahan suspense dalam penyiapan cairan oral dan sebagai bahan untuk meningkatkan viskositas dalam formulasi sedian topikal (untuk penggunaan luar tubuh)., 2,3 Dalam pembuatan sediaan padat, selulosa dan turunannya dapat berfungsi sebagai bahan untuk mengatur sifat pelepasan dari pengantaran obat (pelepasan langsung, terkontrol, pelepasan dihambat). ${ }^{3}$

Pengolahan selulosa biasanya melalui proses kimiawi yang kurang sehat yakni dengan adanya pencucian dengan alkali dan asam untuk memperolah produk selulosa yang murni. ${ }^{4}$ Peningkatan kebutuhan produk turunan selulosa juga akan meningkatkan konsumsi pohon sebagai material mentah dari produk tersebut, sehingga menimbulkan dampak deforesasi yang kemudian menjadi masalah lingkungan global. ${ }^{5}$ 
Namun demikian, masalah diatas dapat dikurangi dengan ditemukan adanya mikroorganisme khususnya bakteri yang mampu menghasilkan selulosa. Brown (1886) mengindentifikasi pertumbuhan folikel tak bercabang yang dihasilkan oleh bakteri yang telah terbukti secara kimiawi memiliki struktur yang sama dengan selulosa yang diperoleh dari tanaman..$^{6,7,8}$ Beberapa genus bakteri yang mampu memproduksi selulosa antara lain Acetobacter, Agnobacterioum, Gluconacetobacter, Rhizobium, Achromobacter, Alcaligenes, Aerobacter, Azotobacter, Rhizobium, Salmonella, Eschericia, dan Sarcina. Bahkan selulosa yang diproduksi oleh jenis Acetobacter dapat digunakan sebagai alternatif makanan dan sebagai bahan utama dalam pembuatan diafragma speaker, bantalan obat dan make up, penebal cat, dan kulit buatan. Selulosa mikroorganisme dapat dirpoduksi dengan mengkultur jenis Acetobakter dan Gluconacetobacter yang sangat mudah dijumpai di buah yang membusuk, sayuran, cuka, jus buah, dan makanan minuman beralkohol. ${ }^{8}$ Pada penelitian ini, kami bertujuan mengisolasi bakteri penghasil selulosa dari buah-buahan yang terdapat pada pasar tradisional di Makassar sehingga dapat menambah keanekaragaman mikroorganisme penghasil selulosa yang nantinya diyakini dapat mengganti kebutuhan selulosa yang berasal dari tanaman. Selain itu kami akan memperhatikan suhu dan $\mathrm{pH}$ optimum produksi selulosa dari isolat penghasil selulosa.

\section{METODE PENELITIAN}

\section{Alat dan Bahan}

Alat yang digunakan dalam penelitian adalah cawan petri, tabung reaksi, oven, autoklaf, inkubator aerob, mikroskop, spoit 1
$\mathrm{mL}$, spoit $5 \mathrm{~mL}$, spoit $10 \mathrm{~mL}$, dan kaca preparat. Bahan yang digunakan dalam penelitian ini adalah Sampel buah segar dan buah yang membusuk (Semangka, Pepaya, Blewah, Mangga, Buah Naga, dan Pisang), D-Glukosa, ekstrak yeast, pepton, Na2HPO4, asam sitrat, dan agar, akuadest, $\mathrm{NaOH}$, Asam asetat, Alkohol $70 \%$, kristal violet, larutan Mordan, larutan alkohol-asam, dan safranin.

\section{Prosedur kerja}

\section{Isolasi Bakteri Penghasil Selulosa}

Sampel buah yang telah dibersihkan dipotong kecil dan dihaluskan. Setiap sampel kemudian ditimbang sebanyak 1 gram dan diinokulasikan kedalam $9 \mathrm{~mL} \mathrm{NaCl}$ fisiologis steril. Kemudian dilakukan pengenceran hingga $10^{-6}$. Setiap pengenceran sampel diambil $1 \mathrm{~mL}$ kemudian dimasukkan kedalam cawan petri. Masukkan $9 \mathrm{~mL}$ medium standar Hestrin-Schramm agar (D-Glukosa $20 \mathrm{~g} / \mathrm{L}$, ekstrak yeast $5 \mathrm{~g} / \mathrm{L}$, pepton $5 \mathrm{~g} / \mathrm{L}$, Na2HPO4 2.7 $\mathrm{g} / \mathrm{L}$, asam sitrat $1.15 \mathrm{~g} / \mathrm{L}$, dan agar $15 \mathrm{~g} / \mathrm{L}$ ). Kemudian diinkubasi selama 48 jam pada suhu $30^{\circ} \mathrm{C}$.

\section{Uji Skrining Bakteri Penghasil Selulosa}

Isolat bakteri tumbuh diambil 1 ose kemudian dimasukkan kedalam tabung reaksi yang berisi $10 \mathrm{~mL}$ medium Hestrin-Schramm cair (D-Glukosa $20 \mathrm{~g} / \mathrm{L}$, ekstrak yeast $5 \mathrm{~g} / \mathrm{L}$, pepton $5 \mathrm{~g} / \mathrm{L}$, Na2HPO4 $2.7 \mathrm{~g} / \mathrm{L}$, dan asam sitrat $1.15 \mathrm{~g} / \mathrm{L})$. Tabung diinkubasi pada suhu $30^{\circ} \mathrm{C}$ selama 7 hari. Setelah inkubasi, tabung dengan lapisan folikel putih diatas permukaan mediumnya dipilih sebagai isolat bakteri penghasil selulosa.

\section{Identifikasi Morfologi Bakteri Penghasil Selulosa}

Isolat bakteri penghasil selulosa yang terpilih diambil 1 ose kemudian dimurnikan dan diamati morfologinya diatas medium Hestrin- 
Schramm agar secara makroskopik. Morfologi yang diamati berupa bentuk koloni, bentuk tepi, bentuk elevasi, dan warna. Untuk morfologi secara mikroskopik, isolate bakteri yang terpilih dicat dengan metode pengecatan gram untuk menentukan jenis bakterinya.

\section{HASIL DAN PEMBAHASAN}

Tabel 1. Hasil Pemurnian dan Skrining Isolat Bakteri Penghasil Selulosa dari Buah-buahan yang berasal dari Pasar Tradisional Makassar

\begin{tabular}{cccc}
\hline NO. & KODE ISOLAT & ASAL BUAH & HASIL UJI SKRINING \\
\hline 1 & MB-B01 & Mangga Busuk & - \\
2 & MB-B02 & Mangga Busuk & + \\
3 & MB-B03 & Mangga Busuk & - \\
4 & MS-B01 & Mangga Segar & + \\
5 & MS-B02 & Mangga Segar & - \\
6 & MS-B03 & Mangga Segar & + \\
7 & NB-B01 & Buah Naga Busuk & - \\
8 & NB-B02 & Buah Naga Busuk & + \\
9 & NB-B03 & Buah Naga Busuk & - \\
10 & NS-B01 & Buah Naga Segar & - \\
11 & NS-B02 & Buah Naga Segar & + \\
12 & PB-B01 & Pisang Busuk & + \\
13 & PB-B02 & Pisang Busuk & + \\
14 & PB-B03 & Pisang Busuk & + \\
15 & PB-B04 & Pisang Busuk & + \\
16 & PS-B01 & Pisang Segar & - \\
17 & PS-B02 & Pisang Segar & + \\
18 & PS-B03 & Pisang Segar & - \\
19 & SB-B01 & Semangka Busuk & - \\
20 & SS-B01 & Semangka Segar & \\
\hline Keterangan:(+) menghasilkan selulosa; (-) tidak menghasikan selulosa &
\end{tabular}

Keterangan : (+) menghasilkan selulosa; (-) tidak menghasilkan selulosa.

Penelitian ini diawali dengan proses isolasi bakteri penghasil selulosa yang berasal dari Buah-buahan baik segar maupun yang telah busuk dari pasar tradisional kota Makassar. Buah yang diisolasi bakteri penghasil selulosa antara lain, Semangka, Pepaya, Blewah, Mangga, Buah Naga, dan Pisang. Isolasi dilakukan dengan medium standar Hestrin-Schramm (HS) agar. HS agar memiliki kadar glukosa yang tinggi serta memeliki sumber nitrogen, vitamin, mineral, dan asam nukleat yang mampu menunjang pertumbuhan bakteri-bakteri yang dapat menghasilkan selulosa. ${ }^{9}$

Hasil isolasi dipilih isolat kemudian dimurnikan hingga diperoleh isolat tunggal. Isolat tunggal kemudian diskrining untuk mengetahui isolat yang mampu menghasilkan selulosa. Untuk uji skrining digunakan medium HS cair agar selulosa yang berbentuk benang dapat mengapung dan membentuk folikel berwarna putih diatas permukaan medium cair (Tabel 1). Isolat yang positif menghasilkan selulosa diidentifikasi secara makroskopik dan mikroskopik (Tabel 2) 
Tabel 2. Tabel karakteristik secara makroskopik dan mikroskopik bakteri penghasil selulosa

\begin{tabular}{|c|c|c|c|c|c|c|c|}
\hline \multirow{2}{*}{ No. } & \multirow{2}{*}{ Kode Isolat } & \multicolumn{4}{|c|}{ Makroskopik } & \multicolumn{2}{|c|}{ Mikroskopik } \\
\hline & & Bentuk Koloni & Tepi & Elevasi & Warna & Gram & Bentuk Bakteri \\
\hline 1 & MB-B02 & Irregular & Lobate & Hilly & Kuning & Negatif & Coccus \\
\hline 2 & MS-B01 & Round & Smooth & Flat & Kuning & Positif & Bacil \\
\hline 3 & MS-B03 & $\begin{array}{l}\text { Round With } \\
\text { Raised Margin }\end{array}$ & Smooth & Raised & Kuning & Negatif & Bacil \\
\hline 4 & NB-B03 & Filiform & Irregular & Hilly & Kuning & Negatif & Coccus \\
\hline 5 & PB-B01 & Round & Smooth & Convex & Putih & Positif & Bacil \\
\hline 6 & PB-B02 & Round & Smooth & Raised & $\begin{array}{l}\text { Kuning } \\
\text { Transparan }\end{array}$ & Negatif & Coccus \\
\hline 7 & PB-B03 & Round & Smooth & Raised & Kuning & Negatif & Bacil \\
\hline 8 & PB-B04 & $\begin{array}{l}\text { Round With } \\
\text { Raised Margin }\end{array}$ & Smooth & Umbonate & Kuning & Negatif & Bacil \\
\hline 9 & PS-B01 & Circular & Lobate & Convex & Kining & Negatif & Coccus \\
\hline 10 & PS-B03 & Concentic & $\begin{array}{c}\text { Wavy } \\
\text { (Undulate) }\end{array}$ & Raised & Putih & Negatif & Coccus \\
\hline
\end{tabular}

\section{KESIMPULAN}

Isolat bakteri penghasil selulosadari Semangka, Pepaya, Blewah, Mangga, Buah Naga, dan Pisang yang diperoleh yakni isolat dengan kode MB-B02, MS-B01, MS-B03, NBB03, PB-B01, PB-B02, PB-B03, PB-B04, PSB01, PS-B03.

\section{DAFTAR PUSTAKA}

1. Keshk SM. Bacterial Cellulose Production and Its Indsutrial Applications. Journal of Bioprocessing \& Biotechniques. 2014; 4(2): 1-10.

2. Edgar KJ. Cellulose Esters in Drug Delivery. Cellulose. 2007; 14(1): 464.

3. Kamel S, Ali N, Jahangir K, Shah SM, ElGendy AA. Pharmaceutical Significance of Cellulose - A Review. wXPRESS Polymer Letter. 2001; 127: 529-542.

4. Sun RC. Detoxification of Biomass of Bioethanol Biosource. 2008; 4(2): 452-455.
5. Park SU, Lee BK, Kim MS, Park KK, Sung WJ, Kim HY. The Possibility of Microbial Cellulose for Dressing and Scaffold Materials. Int. Wound. J. 2014; 11: 35-43.

6. Hestrin S, Schramm M. Synthesis of Cellulose by Acetobacter xylinum. Preparation of Freeze-Dried Cells Capable of Polymerizing Glucose to Cellulose. Biochemical Journal. 1954; 58: 345-352.

7. Donini IAN, Salvi DTB, Fukumoto FK, Lustri WR, Barud HS, Marchetto R. Biosynthesis and recent advances in production of bacterial cellulose. Eclética Quím. 2010; 35: 165-178.

8. Rangaswamy BE, Vanitha KP, Hungund BS. Microbial cellulose production from bacteria isolated from rotten fruit. International Journal of Polymer Science. 2015; 2015(280784): 1-8.

9. Pourramezan GZ., Roayae AM, Qezelbash QR. Optimization of Culture Conditions for Bacterial Cellulose Production by Acetobacter sp. 4B-2. Biotechnology. 2009; 8(1): 150-154. 